\title{
AutORIa COLETIVA EM POESIA, DE ANTÓNIO MARIA LISBOA
}

COLLECTIVE AUTHORSHIP IN POESIA BY ANTÓNIO MARIA LISBOA

http://dx.doi.org/10.11606/issn.2175-3180.v12i22p113-135

Danilo Rodrigues Bueno ${ }^{\mathrm{I}}$

\section{RESUMO}

Poesia, obra póstuma de António Maria Lisboa, organizada por Mário Cesariny, reúne parte da produção do poeta, composta por poemas coletivos, cartas abertas e pessoais, desenhos, bilhetes, textos críticos, manifestos, poemas em prosa e em verso. O livro é atravessado pela presença dos poetas surrealistas, ensejando a percepção de uma obra coletiva, preceito fundamental do surrealismo.

\section{PALAVRAS-CHAVE}

António Maria Lisboa; Autoria coletiva; Jogo; Surrealismo português.

\section{ABSTRACT}

Poesia, posthumous work of António Maria Lisboa, organized by Mário Cesariny, collects part of the poet's production, composed by collective poems, public and personal letters, drawings, notes, critical texts, manifestos, poems in prose and verse. The book is crossed by the presence of surrealist poets, enabling the perception of a collective work, a fundamental precept of surrealism.

\section{KEYWORDS}

António Maria Lisboa; Collective authorship; Game; Portuguese surrealism.

\footnotetext{
I Universidade de São Paulo, São Paulo, Brasil.
} 


\section{NOTÍCIAS SOBRE O AUTOR E SOBRE AS EDIÇ̃̃ES DE POESIA}

António Maria Lisboa (1928-1953) faleceu precocemente, logo após completar 25 anos de idade, vitimado pela tuberculose. Sua obra é reunida e organizada, pela primeira vez, pelo poeta e amigo Mário Cesariny (19232006). A edição compila, entre éditos ${ }^{1} \mathrm{e}$ inéditos, parte daquilo que AML escreveu: aquilo que trazia consigo ou que deixara com amigos, uma vez que outra parte foi descartada pela família, por temor do conteúdo político que pudesse ser rastreado pela PIDE (Polícia Internacional e de Defesa do Estado), responsável pela repressão do regime ditatorial do Estado Novo (1932-1974), que tinha como presidente do Conselho de Ministros António de Oliveira Salazar (1889-1970) a personificação do autoritarismo:

Retomando: após a morte do A. M. L. entram no quarto do poeta: seu pai, que, como Kafka teria preferido ter um Filho Campista, e a sua irmã. Em matéria de textos, rasgam tudo o que apanham e deitam ao lixo [...] Levando ao lixo a obra do mais importante poeta nosso depois de Fernando Pessoa. (CESARINY (org.), 1977, p. 8)

Essa edição é feita em 1962, tendo sido reeditada em 1977, 1995 e $2008,{ }^{2}$ essa última em formato mais popular e acessível sem diferenças significativas com a publicação de 1995. As edições se caracterizam pela reorganização e supressão dos textos, conforme se nota na publicação de 2008, em comparação com a de 1977, ambos os livros são diferentes, tanto na escolha quanto na sequenciação dos textos e no número de páginas, a de 1977 é mais extensa: a diferença mais notável está no apêndice crítico que recolhe 10 textos, suprimido na edição de 2008.

Essa dinâmica de reestruturação textual do livro é a mesma que Mário Cesariny usou para compor a própria obra, com mudanças de

\footnotetext{
${ }_{1}^{1}$ Obra édita, em livro, de AML: (1) Afixação Proibida (1949); (2) Erro Próprio (1950); (3) Ossóptico (1952); (4) Isso Ontem Único (1953), sendo que o item 1 é subscrito por António Maria Lisboa, Henrique Risques Pereira, Pedro Oom e Mário Cesariny. No entanto, depois se descobre que a autoria seria de Cesariny e de Lisboa, com acréscimo da assinatura dos outros dois poetas.

2 A edição de 1962 é da Editora Contraponto, hoje uma relíquia bibliográfica, assim como a obra publicada pelo autor, de 1949 até 1953. As outras são da Editora Assírio \& Alvim.
} 
versos, acréscimos, cortes, além de alterações de sequenciação. ${ }^{3}$ Parece, portanto, que aquilo que Cesariny fez para a sua poesia, ajudou-o a conferir uma ordenação semelhante à obra do companheiro morto. Por essa abordagem, Cesariny pode ser lido como um poeta da reordenação: os princípios reorganizacionais modificam e atualizam o sentido geral da obra, criando leituras que ensejam releituras, além do cotejo entre o que foi feito e o que foi destruído, seguindo a ideia cultivada por AML, apresentada em sua correspondência: "Enriquecimento não no sentido de se construir, mas no de se destruir; precisamente não me enganei DESTRUIR" (CESARINY (org.), 2008, p. 217). Outros poetas relevantes fizeram processos semelhantes: Carlos de Oliveira (1921-1981), Herberto Helder (1930-2015), e, mais recentemente, Joaquim Manuel Magalhães (1945).

Tal decisão editorial pode ser lida como uma autoria em permuta, em conjunto, feita por trocas espaciotemporais, remetendo ao lema de Lautréamont: "a poesia será feita por todos". É de se acreditar que os surrealistas portugueses, ao produzirem uma obra no mesmo contexto, sob o mesmo rigor político do fascismo, além de muitas vezes assinarem os textos juntos, também se influenciaram reciprocamente e produziram uma obra espelhada, em diálogo, feita por trocas e equivalências.

No caso de AML, como aparece já no início de Erro próprio: "a vinda dos NOVOS AMOROSOS" (CESARINY (org.), 2008, p. 25), nota-se a formação de uma comunidade em torno das vivências e das escritas, os agenciamentos coletivos enriquecidos pelas diferenças entre os poetas, pois a relação com o outro é mais fecunda na medida em que se partilha a diferença de cada um, a alteridade enfeixada pelo propósito comum de colocar o inconsciente, o onírico e a aventura como caminhos para a escrita.

Com efeito, o que se extrai da forma de editar de Cesariny é, levando-se em consideração as reorganizações, inclusive dos paratextos ${ }^{4}$ de certos livros, edição a edição, uma concepção de poesia em processo de ressignificação, de sentido flutuante e sempre por fazer. O contato, o convívio e a partilha com AML, os inúmeros (des)encontros, a aventura, a "iluminação profana" (BENJAMIN, 2016, passim p. 21-36) como escreveu

\footnotetext{
${ }^{3}$ Conforme o anexo que efetua um cotejo minucioso da obra de Cesariny, feito por Maria de Fátima Marinho, no livro O Surrealismo em Portugal (1987, p. 473-563).

${ }^{4}$ Na edição de 1977 há uma "nota prévia" (p. 7-15); já na edição de 2008, há um texto inicial intitulado António Maria Lisboa, referido na folha de rosto como "introdução" (p. 7-08) datado de 1958 e uma notícia biográfica (p. 9). Os índices também são diferentes em número e em sequenciação, conforme apêndice ao final do texto.
} 
Walter Benjamin, vivências que permeiam a busca surrealista, criaram a oportunidade de produzir, conservar e publicar certos textos juntos.

\section{PUBLICAC̣̃̃ES DISPERSAS: A RAREFAĈ̣̃O DA OBRA}

A própria noção de obra (completa ou não) está em questão no século XX. A forma de armazenamento da arte, desde Dadá, e, sintomaticamente, depois de Fonte (1917) de Marcel Duchamp, destruída/perdida no mesmo dia em que foi feita, marca um momento em que os artistas lidaram com outras abordagens do arquivo artístico/histórico e passaram a questionar os usos desses arquivos, como, por exemplo, o que propôs Michel Foucault, ao mostrar o arquivo como um sistema de enunciação. ${ }^{5}$ Uma nova forma de compreender a perpetuação da obra passou a se formar, e que excede muitas vezes o suporte do livro e o espaço do museu, bem como confronta as limitações materiais dos arquivos enquanto mantenedores da memória.

No que se refere ao surrealismo português, algo semelhante acontece. Mesmo com o esforço de estudiosos, universidades, museus, notadamente o Centro Português do Surrealismo, ${ }^{6}$ as inúmeras publicações em revistas, acadêmicas ou não, bem como a vasta quantidade de material inédito, vide a correspondência de Cesariny que tem saído nos últimos anos; todo esse esforço de conservação colabora para uma visão ainda parcelar e em aprofundamento dessa produção, caracterizada por um arquivamento tenso entre corpo e obra, entre a performance e o livro, a rarefação mesma da obra. António Cândido Franco chama atenção sobre os desafios de estudar esses textos, o trabalho que ainda está por fazer:

Este trabalho continua por fazer e a História do surrealismo em Portugal, com fecho de portas ou não, tem muito ainda por desbravar. Do mesmo modo se dirá que a hermenêutica, a leitura compreensiva dos traços auditivos e visuais que as várias gerações do surrealismo português deixaram em legado está quase toda ela por fazer. Pouco ou

\footnotetext{
5 “O arquivo é, de início, a lei do que pode ser dito, o sistema que rege o aparecimento dos enunciados como acontecimentos singulares. Mas o arquivo é, também, o que faz com que todas as coisas ditas não se acumulem indefinidamente em uma massa amorfa [...] $\mathrm{O}$ arquivo não é o que protege, apesar de sua fuga imediata, o acontecimento do enunciado e conserva, para as memórias futuras, seu estado civil de foragido: é o que, na própria raiz do enunciado-acontecimento e no corpo em que se dá, define, desde o início, o sistema de sua enunciabilidade" (FOUCAULT, 1987, p. 149).

6 O museu é responsável por variada publicação acerca da produção surrealista em Portugal: https://www.cupertino.pt/centro-portugu\%c3\%aas-do-surrealismo/apresentacao/.
} 
nada se sabe da poesia de António Maria Lisboa, que continua a ser um viveiro infindável de símbolos à espera de leitura analítica e de decifração. A poesia de Mário Cesariny não está em melhor situação; para além das chãs banalidades que sobre ela correm, como essa rábula do realismo, e que um trabalho sério terá de dispensar por confusão, nada sobre ela se conhece (FRANCO, 2012, p. 265-266).

Parece bastante razoável a ideia de que há muito ainda por interpretar, ainda mais se considerar-se que novas gerações farão leituras desprendidas dos afetos e percalços do campo literário português, e, talvez por isso, mais isentas e abertas. Além dos estudos já feitos, há ainda o enorme desafio de ensinar essa produção, que se quer tão distante da matriz racional, ancorada em ferramentas acadêmicas que passam pela ideia de método, estrutura, coesão, lógica etc. Ensinar o surrealismo em sede universitária seria domá-lo, no sentido mais comezinho dessa palavra? Mônica Simas problematiza sobre este tema:

Falar de amor, liberdade e imaginação pessoal no meio acadêmico em acordo com a proposta provocativa dos surrealistas, é enfrentar um terreno, por assim dizer, pantanoso, desfavorável, porque a "academia" geralmente é associada à perpetuação do controle do imaginário e à formulação de discursos de coerência. (BUENO et al, 2007, p. 329)

O que acontece com o ensino do surrealismo, então, é a submissão à sua própria historicidade, como se os "fatos" e as "datas" se sobrepusessem a qualquer outro aspecto dessa produção, devorando as suas particularidades e, muitas vezes, a extensibilidade da sua interpretação, principalmente acerca de sua vertente mística e onírica. Em um sentido mais amplo, disciplinas necessárias para o estudo do surrealismo seriam a alquimia, a magia, a psicanálise, o hermetismo entre outras, deslocando-se a razão como única produtora de discursos, ou, ainda, colocando-se a razão como apenas outra forma de abordagem.

Além desses dois pontos, quais sejam: o muito que ainda há por estudar e a dificuldade de ensino em sede universitária, pode-se ainda apontar a escassez das fontes, quase todas publicadas em Portugal, sem edições brasileiras e com pouquíssima divulgação em ambientes que não sejam os de pós-graduação. A essas dificuldades exegéticas, pedagógicas e bibliográficas somam-se ainda extensas polêmicas acerca dos grupos 
surrealistas, que por vezes assumem o primeiro impulso de leitura, deixando de lado a percepção mais próxima da produção dos artistas.

No que se refere às dificuldades bibliográficas, pode-se citar o caso de $A$ afixação proibida, texto manifesto que abre a edição de 2008. Assinado por António Maria Lisboa, Henrique Risques Pereira (1930-2003), Pedro Oom (1926-1974) e Mário Cesariny (vide nota 1), esse texto também consta no volume Actuação escrita (1980), reunião póstuma dos textos de Oom, além de figurar em outras obras de caráter coletivo sobre o surrealismo português, criando um círculo de edições ao redor dele. Essa publicação, fundamental em muitos sentidos, crivada de controvérsias autorais, demarca o autor coletivo e o testemunho de um tempo convulso, principalmente acerca dos autógrafos. $\mathrm{O}$ nó autoral decorre ainda pelo fato de Oom e Risques Pereira terem sido incluídos no manifesto, aparentemente sem autorização prévia, e também do fato de que MárioHenrique Leiria (1923-1980), ter-se solidarizado com o texto depois de sua divulgação, em uma espécie de ratificação a posteriori, como se quisesse assiná-lo depois de sua divulgação, ideia plausível ao se pensar no contexto de atuação dos poetas, em discussões e movimentos constantes, permeados de (re)encontros, pelo menos entre 1949-1953, fazendo com que essa produção possa ser abordada como de autoria coletiva, afeita à contaminação e ao livre trânsito das ideias. Com isso, há um caráter difuso e dispersivo desses textos, tanto no que se refere à autoria quanto ao que se refere às entradas bibliográficas que eles podem suscitar.

A despreocupação na fixação dos textos e das autorias remete à oposição de vida literária face a aventura da vida (a vida total proposta pelo surrealismo), bem como abre espaço para entender a rarefação da obra como um gesto performático. A discussão sobre a autoria enseja um debate estimulante na teoria literária das últimas décadas, conforme se verá rapidamente agora, com a finalidade de desdobrá-la, ainda que parcialmente, no âmbito do surrealismo português.

\section{EXCURSO SOBRE AS NOÇÕES DE AUTORIA E OUTRA VISÃO DO COLETIVO}

As teorias sobre o autor são amplas e antigas. De forma arbitrária, serão abordadas apenas uma parte dessa discussão, a partir do romantismo. 
Em 1798, Novalis escreveria sobre a importância do leitor, capaz de construir toda a massa de leituras e interpretações de um texto, o leitor seria um agente ativo, um "espírito eficaz":

O verdadeiro leitor tem de ser o autor amplificado. É a instância superior, que recebe a causa já preliminarmente elaborada da instância inferior. O sentimento, por intermédio do qual o autor separou os materiais de seus escritos, separa novamente, por ocasião da leitura, o que é rude e o que é formado no livro - e se o leitor elaborasse o livro segundo a sua ideia, um segundo leitor apuraria ainda mais, e assim, pelo fato de a massa elaborada entrar sempre de novo em recipientes frescamente ativos, a massa se torna por fim componente essencial membro do espírito eficaz. (NOVALIS, 2009, p. 103)

Novalis descreve o curso exponencial da leitura, cada leitor constrói uma parte do edifício das sucessivas interpretações, colocando o autor como "instância inferior", no princípio, o próprio evento originário das redes de significações de um texto.

Já no século $\mathrm{XX}$, a discussão acerca do estatuto do autor (território teórico em que a obra e o leitor surgem dinamicamente) teve contribuições significativas. Em 1959, Maurice Blanchot, ao recuperar o conto "Pierre Menard, autor del Quijote" (1939), de Jorge Luis Borges, colabora para questionar várias questões sobre a autoria, principalmente pela percepção de que Menard, autor francês do século XX, teria uma "obra visível" e outra, a "subterrânea" e "inconclusa" (BORGES, 2016, p. 113-116): escrever três capítulos que coincidissem exatamente com o texto de Cervantes letra a letra, tal qual ele é, sem copiá-lo e sem qualquer ajuda mecânica. Esse texto seria ainda mais rico, mesmo em fragmento, ${ }^{7}$ do que o original de Cervantes, por incorporar todos os discursos anteriores sobre ele, por acumulação:

Borges compreende que a perigosa dignidade da literatura não é a de nos fazer supor, no mundo, um grande autor absorto em suas mistificações sonhadoras, mas a de nos fazer sentir a aproximação de uma estranha potência, neutra e impessoal. (BLANCHOT, 2005, p. 139)

\footnotetext{
${ }^{7}$ Nota-se, da leitura do conto, a ideia da fragmentação da obra como uma tópica do século XX, notadamente da produção da vanguarda europeia. Borges expõe essa fragmentação como uma característica admirável, positiva.
} 
Desloca-se a atenção ao autor para transformá-lo em potência, um mediador, descarregado de significado histórico e social, desideologizado, pronto a propiciar o contato com a força da obra, sua aparição e sentido.

Em 1967, Roland Barthes irá declarar a morte do autor, colocandoo como uma instância desnecessária para a instauração do discurso, apoiado nas pesquisas da linguística, ao preconizarem "que a enunciação em seu todo é um processo vazio que funciona perfeitamente sem que seja necessário preenchê-lo com a pessoa dos interlocutores" (BARTHES, 2012, p. 60). Além dessa justificativa linguística, ele acresce também o papel que o surrealismo teve para mitigar a importância do autor:

O Surrealismo, finalmente, para nos atermos a essa pré-história da modernidade, não podia, sem dúvida, atribuir à linguagem um lugar soberano, na medida em que a linguagem é sistema, e aquilo que se tinha em mira nesse movimento era, romanticamente, uma subversão direta dos códigos - aliás ilusória, pois um código não pode se destruir pode-se apenas "jogar" com ele; mas recomendado sempre frustrar bruscamente os sentidos esperados (era a famosa "sacudida" surrealista), confiando à mão o cuidado de escrever tão depressa quanto possível aquilo que a cabeça mesma ignora (era a escritura automática), aceitando o princípio e a experiência de uma escritura coletiva, o Surrealismo contribui para dessacralizar a figura do Autor. (BARTHES, 2012, p. 60)

A justificativa de Barthes elucida um ponto central do surrealismo, seu caráter coletivo, a ideia de "jogar" com os sentidos do código para alcançar uma "escritura" coletiva, a escrita automática como um processo de unificação entre os "jogadores" da obra.

Assim se desvenda o ser total da escritura: um texto é feito de escrituras múltiplas, oriundas de várias culturas e que entram umas com as outras em diálogo, em paródia, em contestação, mas há um lugar onde essa multiplicidade se reúne, e esse lugar não é o autor, como se disse até o presente, é o leitor: o leitor é o espaço mesmo onde se inscrevem, sem que nenhuma se perca, todas as citações de que é feita uma escritura; a unidade do texto não está na sua origem, mas no

\footnotetext{
${ }^{8}$ O texto originalmente saiu em 1967 em uma publicação coletiva promovida pelo periódico Aspen, dos EUA; tratava-se de uma caixa compartilhada por vários outros artistas importantes, entre eles Beckett, Burroughs, Butor, Cage, Duchamp, Sontag, entre outros. A natureza da edição era de caráter artístico e vanguardista e continha vários suportes: texto, filme, imagem e música, o que enseja o tom propositivo, próximo ao manifesto, do qual se reveste o texto de Barthes.
} 
seu destino, [..] é preciso inverter o mito: o nascimento do leitor deve pagar-se com a morte do Autor. (BARTHES, 2012, p. 64)

A reverberação dessa leitura ocorre logo depois, em 1969. Michel Foucault trataria por desenvolver novos caminhos com a conferência " $\mathrm{O}$ que é um autor?", espécie de revisão e desdobramento das ideias de Barthes. $\mathrm{O}$ que ele propõe pode ser verificado, em síntese extrema, na passagem: "a marca do escritor não é mais do que a singularidade da sua ausência; é preciso que ele faça o papel do morto no jogo da escrita" (FOUCAULT, 2015, p. 273). Desloca-se a discussão para além do desaparecimento do autor, busca-se uma abordagem que parte do seguinte argumento: se o autor está morto, não seria necessário, então, buscar novos aparatos para a sua compreensão? perspectiva que gera a proposta da função autor, ${ }^{9}$ que busca integrar o autor novamente na dinâmica das teorias da leitura já que se torna necessário "localizar o espaço assim deixado vago pela desaparição do autor, seguir atentamente a repartição de lacunas e das falhas e espreitar os locais, funções livre que essa desaparição faz aparecer" (FOUCAULT, 2015, p. 275). Ou seja, ler a partir da morte do autor, morte essa incapaz de cessar o interesse desta instância discursiva enquanto produtora de sentido, ao contrário, o autor distribuise agora em funções que direcionam as interpretações dos discursos.

Mais recentemente, Giorgio Agamben, ao comentar as ideias de Foucault, chega a formulações que influenciam as dinâmicas de leitura. Para ele, a leitura ocuparia o espaço de um gesto:

O lugar - ou melhor, o ter lugar - do poema não está, pois, nem no texto nem no autor (ou no leitor): está no gesto no qual autor e leitor se põem em jogo no texto e, ao mesmo tempo, infinitamente fogem disso. O autor não é mais do que testemunha, o fiador da própria falta na obra em que foi jogado; e o leitor não pode deixar de soletrar o testemunho, não pode, por sua vez, deixar de transformar-se em fiador do próprio inexausto ato de jogar de não se ser suficiente. (AGAMBEN, 2007, p. 62-63)

\footnotetext{
${ }^{9}$ De forma esquemática, seriam quatro funções apresentadas na conferência "O que é um autor?": 1 - a impossibilidade de delimitar e descrever o que seria um autor e ao mesmo tempo de tratá-lo como nome comum; 2 - a apropriação feita pelo autor que não o credencia a ser, forçosamente, o proprietário do texto; 3 - a atribuição de um autor a um texto parte de mecanismos complexos e dificilmente justificáveis pela incerteza da obra; e 4 - a posição do autor no livro (prefaciador, copista, narrador, confidente, memorialista etc.) e a posição do autor em relação aos diferentes discursos e ao campo discursivo (cf. FOUCAULT 2015: p. 268-269).
} 
Essa ideia gera um pacto - tentador dizer uma regra no jogo da leitura - entre autor e leitor, um arranjo coletivo entre as duas instâncias, sem hierarquizações. Esse gesto seria a forma renovada das interpretações que os leitores poderiam fazer para o espaço vazio deixado pelo autor:

\begin{abstract}
Mas de que maneira uma paixão e um pensamento poderiam estar contidos em uma folha de papel? Por definição, um sentimento e um pensamento exigem um sujeito que os pense e experimente. Para que se façam presentes, importa, pois, que alguém tome pela mão o livro, arrisque-se na leitura. Mas isso pode significar apenas que tal indivíduo ocupará no poema exatamente o lugar vazio que o autor ali deixou, que ele repetirá o mesmo gesto inexpressivo através do qual o autor tinha sido testemunha de sua ausência na obra. (AGAMBEN, 2007, p. 62)
\end{abstract}

Depois dessa rápida revisão das noções de autoria, é possível transpor algumas dessas ideias para o âmbito do surrealismo português. Nesse deslocamento, Mário Cesariny torna-se uma figura incontornável, principalmente em sua relação com AML, dada a sua atuação ampla no contexto de produção da arte portuguesa, com mais de 60 anos de aventura surrealista, a ponto de instigar a imaginação como se fosse "um Dalí à portuguesa" (FRANCO, 2019, p. 17), como António Cândido Franco o construiu mentalmente antes do primeiro contato pessoal com o artista.

Com efeito, Cesariny, ao fazer traduções, críticas, pinturas, objetos, performances, textos entre outros, torna-se o ponto comum da multiplicidade e da transdiscursividade, o causador dos diálogos e das inter-relações entre as artes que explora, do gesto entre autor e leitor, ou, no caso português, entre artista e artistas, o ponto pelo qual o coletivo atravessa.

No caso de Cesariny, a ideia de obra passa pelo eixo místico e pela acumulação de funções e atuações autorais e coletivas. Em que pese o exemplo aleatório: Cesariny traduz excertos de Novalis, do francês, ${ }^{10}$ convive com a obra do romântico alemão por meio de tradução indireta, tamanha é a necessidade de diálogo com um poeta que admira, verte para o seu idioma como uma convocação em diálogo, por meio do jogo da tradução (aliás, jogo por excelência, território crítico que impõe um mosaico de leituras teóricas, inclusive de noções sobre o coletivo). Os interesses são

${ }^{10}$ Novalis. Fragmentos. tradução de Mário Cesariny. Lisboa: Editora Assírio e Alvim, 1986. 
amplos: pinta, desenha, escreve poemas, ensaios, faz edições, troca inúmeras cartas com surrealistas, planeja exposições, de modo a exercer uma intervenção de alcance muito amplo, inserindo-se em várias discursividades e ressignificações. A proliferação dos gêneros e das artes praticadas por Cesariny suscita uma enorme massa de relações, podendo representar a própria noção contingente do vivido e da percepção humana.

Nesse viés, busca-se entender, em deriva, o termo "coletivo" também no que se refere aos contatos interartes e às contaminações dos gêneros textuais entre si, em uma ampliação, ou talvez fosse melhor chamar distorção, do conceito relacionado à autoria individual ou coletiva. A recolha poética de AML é exatamente o exemplo dessa conjunção de gêneros em uma coletivização chamada que Cesariny convencionou chamar Poesia (mas poderia ter outra nomenclatura totalizadora, como obra ou vida), e que traz, cartas, bilhetes, desenhos, conferências etc. Nessa interpretação, os gêneros textuais, bem como o verso ao lado do desenho, criam contatos por semelhança e por dissemelhança. O heteróclito dos materiais produzidos colabora em uma percepção expansiva e aberta, que ajuda a entender a multiplicidade daquele momento, as rupturas e os deslizamentos que o surrealismo português propunha, como signo do exercício da liberdade.

Ao se admitir tal uso da palavra "coletivo", deslocada agora para a formalidade da estrutura verbo-visual da obra, ele produz uma convergência genológica que maximiza os discursos - espécie de obra total - uma das buscas do surrealismo; estratégia tributária às matrizes do absoluto romântico, daí, talvez, a urgência de Novalis figurar na palheta de referências do artista português.

\section{DISPOSITIVOS DA AUTORIA COLETIVA: A DEDICATÓRIA COMO GESTO AMOROSO}

É notável, na edição de 1977, a seção intitulada "A poesia feita por todos", constante entre as páginas 17-124, ou seja, boa parte das 409 constantes do volume, título de seção que desaparece na edição de 2008. Essa seção compila poemas coletivos, carta e textos poéticos/programáticos e demarca um argumento muito forte sobre a autoria coletiva na obra de AML. Além dessa referência explícita, busca-se outros engendramentos dos dispositivos de autoria coletiva em Poesia. Pode-se considerar, inicialmente, alguns mecanismos, quais sejam: textos coletivos ou a quatro mãos (autoevidentes); referências aos companheiros no texto, que podem 
sugerir intertextualidades; intertextualidades diretas com a obra dos companheiros; paratextos como nota prévia, introdução e dedicatórias; cartas e bilhetes que discutem a obra etc.

Dado o propósito desse artigo e o espaço reduzido para uma busca tão ampla dos dispositivos autorais referidos acima, escolhe-se, com o propósito de uma tentativa de aproximação, o paratexto da dedicatória, que funciona como homenagem e diálogo, além de criar endereçamentos profícuos entre os autores, perpassados pela noção da busca amorosa, tão cara ao pensamento de AML.

As dedicatórias sugerem trocas prévias com os homenageados, no caso de AML, os companheiros de surrealismo. Desse modo, pensa-se nela como uma resposta a uma conversa anterior, em um movimento de continuidade, semelhante a uma correspondência que culmina com o poema, corolário do diálogo. Essa comunidade surrealista, por meio de encontros em cafés e em lugares públicos, além das cartas e bilhetes trocados, podem ser vistos como criadores de atos repetidos e que podem ser lidos como mágicos, ${ }^{11}$ dada a repressão fascista, a regularidade dos encontros dos poetas, o clima misterioso e proibido em que essas escritas tomaram forma.

Em Ossóptico, dos dezoito poemas da edição organizada para 2008, seis trazem companheiros em dedicatória e outros cinco possuem nome próprio no título, o que pode suscitar também uma noção de endereçamento. Além disso, o poema que encerra o livro, "Cadame", é escrito junto com Mário Cesariny. Na edição de 1977, Ossóptico, por sua vez, tem quinze poemas, acrescidos de dois desenhos de AML dedicados, um para Pedro Oom e outro para Mário Henrique, além de um esboço de autoria de Risques Pereira para o livro, que se chamaria inicialmente "Osso Exótico", a troca do título é uma evidência anterior da importância do diálogo e do convívio entre eles. Leia-se um poema dedicado de Ossóptico:

\section{ESTRELA DE TODAS AS HORAS}

Para o Henrique Risques Pereira

Estrela da Ilha de Puros Ministros do Amor

\footnotetext{
${ }^{11}$ Adota-se a noção de magia de empréstimo do antropólogo Marcel Mauss: “Obtivemos, assim, uma definição provisoriamente suficiente do rito mágico: qualquer rito que faça parte de culto organizado, rito privado, secreto, misterioso e tendendo, como limite, para o rito proibido [...] Vê-se que não definimos a magia pela forma dos seus ritos, mas pelas condições em que eles se produzem e que marcam o lugar que ocupam no conjunto dos hábitos sociais" (MAUSS, 2000, p. 23).
} 
Estrela da Tarde que acredita sempre na possibilidade da existência Estrela do Meio-dia Antes e Depois da Nossa Época

Estrela da Noite de Todas as Cores

Estrela da Madrugada que traz sempre a esperança agrilhoada

Estrela da Manhã - os Mistérios de Ísis e Osíris - eu ainda menino.

No Alto um Piloto por caminhos secretos.

Nos Gumes tudo que não possa durante este tempo mergulhar como dois personagens distintos

num seio enorme de mármore nu

não pode fazer mais do que arrastar-se atrás dum Grande Carro.

ESTRELA DE TODAS AS HORAS - ODASASHOR-ASEST-R

mil novecentos e cinquenta

um pássaro de granito.

(CESARINY (org.), 2008, p. 76)

No poema transcrito, AML repete anaforicamente a palavra "estrela", 12 o que causa um efeito de realce e de convocação mágica, além de retomar o inventário, técnica de repetição muito usada no surrealismo. A oferta do poema ao Henrique Risques Pereira cumulada à data ao final, que contextualiza a relação entre ambos "mil novecentos e cinquenta", pode ensejar um espaço de partilha prévia, de trocas sistemáticas entre eles. Essa ideia se adensa, se, ao lado do poema, for colocado esse bilhete de AML, escrito em 1948:

Henrique amigo.

Vou amanhã sábado a Lisboa. Só hoje me apeteceu escrever e mesmo assim algo de esquemático pretendo fixar. Tenho chegado a lindas conclusões embora tudo esquemático, mais ou menos... Em algumas coisas cheguei a sínteses engraçadas.

Estou no Café Chiado às 2,30 horas da tarde de sábado. Vê-se podes lá chegar. Se o não puderes fazer estou em tua casa por volta das 8 para as 9 horas. Se não te encontrar na Smarta entre as 9 e as 10;45

\footnotetext{
12 Note-se a importância do signo estelar para AML, conforme as palavras de Joana Lima: “A poesia "resplandece" do fogo, símbolo de transformação e de devir, do qual "milhares de estrelas" são metáfora. A esta afirmação basilar seguir-se-ão muitas referências a astros, ao cosmos, ao fogo, que constituem um campo semântico astral sugerindo misticismo, verticalidade e ascese, como no poema dedicado ao amigo Henrique Risques Pereira, “Estrela de Todas as Horas" (LIMA, 2017, p. 89).
} 
horas. Depois na Estação do cais do Sodré para apanhar o comboio das 11,30 horas. (CESARINY (org.), 2008, p. 158)

Notam-se as táticas de interação e de acompanhamento da obra ("sínteses engraçadas"). O poema dedicado, portanto, poderia ser uma das (d)obras de uma conversa, trocada nestes encontros (des)programados pela cidade lisboeta, mostrando uma aproximação artística que cria traçados geográficos e afetivos, em trânsito. Pode-se argumentar que os caminhos da escrita são discutidos e feitos juntos, pelos caminhos da cidade, em movimento e aventura, signo, talvez, do inconsciente coletivo. A obra, ou melhor, certa ideia de obra, se amplia também para os encontros e conversas, em que a performance e o jogo entre os poetas permitiram algum arquivamento que tomou a forma do poema, mas que deixou que muito se tornasse inapreensível, meramente suposto, entrevisto, convivido, com o reenvio sugerido pela dedicatória.

Essa dedicatória de caráter público, uma vez que acompanha um poema, reunido ainda por outro poeta, Cesariny, registra e demarca a afinidade eletiva entre os poetas, o gesto de autor e leitor, ou melhor, de poeta e poetas, para se recuperar a ideia de Agamben. É nesse passo que a palavra "estrela", também ela síntese do pensamento de AML, aparece como nexo entre os poetas. Se para AML "estrela" significa poesia, conhecimento, "verdadeira vida", então o Henrique Risques Pereira seria o endereçado desse momento total, dessa descoberta, convocado e relembrado pelo poema na direção de um (re)encontro superior entre eles.

\section{A DESTRUIÇÃO COMO PARTE DA OBRA}

O pai de AML, ao destruir parte de seus papéis em temor à PIDE, age como uma espécie de autor, ainda que em negativo, ao dar um sentido final ao que AML teria escrito. Esse biografema é constituinte da visão de Cesariny, que levava em alta conta a capacidade do amigo morto precocemente, conforme a apresentação ao volume de 2008:

Partido da libertação surrealista, o pensamento poético António Maria Lisboa aprisionou a ave hierática com que, até hoje, só os asiáticos e certos primitivos têm modulado a chamada vida prática. (Mas não foram os poetas chineses os criadores, há 2062 anos, do jogo poético coletivo "inventado" pelos surrealistas, há dois dias?) Os termos da obra de António Maria Lisboa, de um desenvolvimento extra- 
individual de aferição da Verdade, da Justiça e do Bem, não inquirem, impõem as condições de sua perenidade. (CESARINY (org.), 2008, p. 8)

As "condições de sua perenidade" são alheias ao ato destrutivo do pai, e, curiosamente, reproduz ideia de AML já referida: destruir é melhor que criar. Por essa perspectiva, Poesia de AML é ao mesmo tempo escrita que foi salva e salvífica. O pai de AML, pela leitura aqui proposta, participa desse jogo com o ato da destruição, talvez para proteger o filho, talvez para se proteger, pouco importa, ele colabora performaticamente na negação da existência de uma obra em processo de construção e partilha, sendo o descarte, um dos elementos de sua mensagem final.

A maneira como Cesariny construirá AML em relação ao pai que leva "ao lixo a obra do mais importante poeta nosso depois de Fernando Pessoa" (op. cit.) é uma forma de elevar e instigar a aura perdida do poeta, mal comparando, assumiria contorno simbólico similar ao silêncio de Rimbaud, como pode se verificar na "Nota Prévia" escrita por Cesariny para a edição de 1977:13

A dispersão de textos inéditos ou não inéditos, dispersão odiosamente contrária ao desejo de António Maria Lisboa que, de Sanatório em Sanatório, de Casa de Saúde em Casa de Saúde cuidadosamente os transporta, conserva e trabalha - os "enriquece" na própria expressão do poeta, através da experiência que deve ser prosseguida e que não cessará com a entrada numa câmara mortuária. (CESARINY (org.), 1977, p. 7)

Da mesma forma que aquilo que foi destruído é irrecuperável, a "dispersão" da obra de AML deve ser compreendida por meio desses agenciamentos coletivos, quais sejam: a vivência dos encontros pelas ruas, as dificuldades e as mudanças de casas de saúde, a discussão da obra por bilhetes e pelas cartas, as dedicatórias e as apresentações, e, no extremo, o gesto destrutivo do pai, ações que geram a construção coletiva da obra, pois nunca será possível apurar ao certo se ele teria a obra mais relevante depois de Pessoa, já que existe apenas uma visão parcial, daquilo que foi a "dispersão" dela. Além disso, a morte precoce do poeta colabora para a

\footnotetext{
${ }^{13}$ Curiosamente, a edição de 1977 tem uma "Nota Prévia" de nove páginas e a edição de 2008 tem uma "Introdução" de uma página e meia, como se os próprios paratextos constituíssem alvos de ressignificações genológicas.
} 
construção desse biografema de poeta "silenciado" durante o vigor da juventude, em paralelo à tópica rimbaudiana.

\section{REENCONTRO E DESPEDIDA}

O poema abaixo encerra Ossóptico, de forma a se perceber um reencontro e uma despedida:

cadame

A vida é bela $\bullet$ comecemos

Primeiro: o maior descanso

Segundo: a maior liberdade

Terceiro: o tratar-se dos pés

Quarto: queimar

Vejamos: a lua no quarto crescente cinge o macaco. Separará sem dúvida o quente do frio, como uma aterrissagem do génio expelindo o melhor, le plus beau que auferimos de tanta felicidade. Partiremos de noite como dois operários. Assim eu venho para a grande fractura frente ao palácio. A princesa repousa da sua casa, trago-lhe o direito de abandono nela. E encarregado da obra e da palavra, amigo da bondade e da beleza, o meu cão.

Olhar é desaparecer.

Abre a janela e passa orgulhoso

sob o aqueduto

o avião o

silêncio.

Além de tudo o novo cisne de Rhodes teu pai, pai de si mesmo é de quantos o habitam, ele que tanto lembra o seu esplêndido vácuo e fala claramente separado mundo.

Quanto a Fausto, é de ver que se trata de gente doida com aparência de

sábios, gente que sabe, que sabe muito, gente para fuzilar,

Le vieux couple.

Cadame.

Le soleil.

António Maria Lisboa, Mário Cesariny Vasconcelos 
Hospital de S. Luís dos Franceses, Lisboa, 1953.

(CESARINY (org.), 2008, p. 83-84)

A assinatura a quatro mãos, a data (ano da morte de AML, recordese), a localidade de um hospital, depreendendo-se já a doença avançada; esses índices colaboram para a percepção da poesia enquanto (re)encontro e celebração, mesmo na situação mais adversa e dificultosa entre os amigos.

A mistura de verso e prosa e o uso de português e francês demarcam duplas que deixam inferir a parceria entre os poetas, o 1 mais 1. O primeiro verso: "A vida é bela • comecemos", com um círculo negro ao meio, cria uma espécie de verso bimembre, fazendo com que graficamente a noção de duplo também se instaure. Esses duplos revelam-se no jogo performático do (re)encontro.

O uso da primeira pessoa do plural não é somente um efeito retórico para incluir o leitor, mas é acima de tudo aquilo que congrega AML e Cesariny, o convite para o jogo da autoria coletiva, vale dizer, para a existência juntos, já que "a vida é bela" como afirma o adágio popular. É possível perceber um desprendimento que faz com que uma leitura lúgubre ou elegíaca escape, não cubra a margem que esse poema sugere, ainda que AML estivesse já muito doente.

A segunda estrofe carrega uma espécie de súmula surrealista: ócio, liberdade e morte, ao lado dos necessários cuidados com os pés, chiste que dá a ver as disparidades e os insólitos volteios do inconsciente. Ao mesmo tempo que a cena é ritual e hermética - dada a proximidade da morte - o jogo se instaura entre eles, o que aponta certa totalidade que a "metaciência"14 de AML buscava.

A terceira estrofe, em prosa, muda o ritmo do poema, mimetizando, por essa alteração rítmica, a instabilidade do mundo. Parece uma tentativa de marcar bruscamente uma passagem, uma nova forma de respiração. É o momento do poema que mais se assemelha à escrita automática, o fluir de imagens, em velocidade, cria uma sequência ao mesmo tempo narrativa e insólita.

O verso solto que perfaz a quarta estrofe, em caráter de adivinha oracular, requer uma postura ativa do leitor, agora convocado para o jogo

\footnotetext{
14 AML preferia metacientista, ao invés da definição surrealista, que envolvia submissões a grupos e compromissos literários.
} 
coletivo do poema, ao mesmo tempo que integra a sua paisagem "clínica", o ritual de reencontro e despedida entre os amigos. Além disso, há o retorno para o registro em verso, ou seja, para o ritmo da poesia. Se "olhar é desaparecer", fundir-se com a paisagem e com o todo (com o outro, talvez) entende-se uma percepção de caráter místico, um aprendizado de morte, uma percepção alquímica da destruição (da obra e do corpo) compreendida pelo (talvez) último jogo entre os companheiros. Desse modo, em mais uma "sessão", 15 como Cesariny costuma referir a procedência de certos textos, emaranham e assumem a ideia de que o fim é um novo começo, a buscada anulação dos contrários da estética surrealista e hermética. ${ }^{16}$

A quinta estrofe abre o poema para o espaço exterior delineado por "aqueduto" e "avião", em um olhar para fora, congelado pelo silêncio. Esses espaços colaboram para colocar uma moldura na cena do reencontro, para perspectivá-lo, aumentando a solitude dos amigos, pontuando-se, ao longe, a desnecessária continência do mundo. $\mathrm{O}$ avião pode ser visto também como signo bélico, de autoridade e de repressão, metonímia da "soberania nacional". Não se pode olvidar que se trata de um contexto ainda muito próximo à bomba atômica e às feridas da Segunda Grande Guerra (1939-1945). Por fim, pode-se referir a antítese entre "aqueduto" (antigo) e "avião" (moderno), gerando uma leitura que implica totalidade e fusão a partir dela.

A sexta e última estrofe do poema instaura uma mancha gráfica indecisa entre verso e prosa, bem como retoma a ideia de fusão e totalidade, a indecidibilidade quanto ao gênero das vozes coletivas que perpassam o poema, as superposições de planos, de registros e de idiomas, já que o encerramento é em francês. Do cisne de Rhodes para Fausto e depois para a "o casal de velhos" e o sol (que possui imensa simbologia, inclusive de renascimento).

O significado do vocábulo "Cadame" apresentou-se de forma misteriosa e hermética. Pode-se pensar em neologismo, ou em alguma

\footnotetext{
15 Vide a seção “Notas ao texto” (CESARINY (org.), 1977, passim p. 385-409).

16 Conforme o Segundo Manifesto do Surrealismo (1930): “Tudo leva a crer que existe um determinado ponto do espírito donde a vida e a morte, o real e o imaginário, o passado e o futuro, o comunicável e o incomunicável, o alto e o baixo, deixam de ser apreendidos contraditoriamente. Ora, em vão procuraríamos para a actividade surrealista outro móbil além da esperança de determinação deste ponto" (BRETON, 1969, p. 152). De acordo com a Tábua da Esmeralda, texto alquímico de Hermes Trimegisto: “O que está em baixo é como o que está no alto, e o que está no alto é como que está em baixo; por essas coisas fazem-se os milagres de uma só coisa" (MACHADO, 1991, p. 63).
} 
linguagem cifrada, ou até mesmo em alguma charada fonética, ocorre que não houve acepção, nos dicionários consultados, para essa palavra nem em francês nem em português. Esse obscurecimento do sentido realça o sabor de adivinha oracular, e ritualiza as vivências "metacientíficas", nesse coral de vozes, em trânsito pela experiência dos poetas.

\section{REFERÊNCIAS}

AGAMBEN, Giorgio. "O autor como gesto". In: Profanações. Trad. Selvino José Assmann. Belo Horizonte: Autêntica, 2007. p. 55-63.

BARTHES, Roland. "A morte do autor". In: O rumor da língua. 3a. ed. Trad. Mário Laranjeira. São Paulo: Brasiliense, 2012. p. 57-64.

BENJAMIN, Walter. "O Surrealismo - o último instantâneo da inteligência europeia". In: Obras escolhidas I. Trad. Sergio Paulo Rouanet. São Paulo, Editora Brasiliense, 2016. p. 21-36.

BLANCHOT, Maurice. "O Infinito literário: o Aleph". In: O Livro por vir. Trad. Leyla Perrone Moisés. São Paulo: Martins Fontes, 2005. p. 136-140.

BORGES, Jorge Luis. "Pierre Menard, autor del Quijote". In: Cuentos completos. 7a. ed. Buenos Aires: Debolsillo, 2016. p. 113-122.

BRETON, André. Manifestos do surrealismo. Trad. Pedro Tamen. Lisboa: Moraes Editores, 1969.

CESARINY, Mário (org). Poesia de António Maria Lisboa. Lisboa: Editora Assírio \& Alvim, 1977.

CESARINY, Mário (org). Poesia de António Maria Lisboa. Lisboa: Editora Assírio \& Alvim, 2008.

FOUCAULT, Michel. A arqueologia do saber. 3a. ed. Trad. Luiz Felipe Baeta Neves. Rio de Janeiro, Editora Forense Universitária, 1987.

FOUCAULT, Michel. "O que é um autor". In: Estética: literatura e pintura, música e cinema. 4a. ed. Trad. Inês Autran Dourado Barbosa. Rio de Janeiro, Editora Forense Universitária, 2015. p. 268-302.

FRANCO, António Cândido. Notas para a compreensão do Surrealismo em Portugal. Évora: Editora Licorne-CEL, 2012. 
FRANCO, António Cândido. O triângulo mágico - uma biografia de Mário Cesariny. Lisboa: Editora Quetzal, 2019.

LIMA, Joana. António Maria Lisboa: eterno amoroso. Lisboa: Edições Colibri, 2017.

MACHADO, Jorge. O que é alquimia. São Paulo: Editora Brasiliense, 1991.

MARINHO, Maria de Fátima. O Surrealismo em Portugal. Évora: Editora Imprensa Nacional-Casa da Moeda, 1987.

MAUSS, Marcel. Esboço de uma teoria geral da magia. Trad. Paulo Neves. Lisboa: Edições 70, 2000.

NOVALIS, Friedrich von Hardenberg. Pólen. Trad. Rubens Rodrigues Torres Filho. São Paulo: Editora Iluminuras, 2009.

NOVALIS, Friedrich von Hardenberg. Fragmentos. Trad. Mário Cesariny. Lisboa: Editora Assírio e Alvim, 1986.

OOM, Pedro. Actuação escrita. Lisboa: Editora \& etc, 1980.

SIMAS, Monica. "O surrealismo português em perspectiva". In: BUENO et al. Literatura Portuguesa: história, memória e perspectivas. São Paulo, Editora Alameda, 2007, p. 329-336. 


\section{APÊNDICE DUAS EDICÕES DE POESIA: COMPARAC̄̃o do “PLANO” dE 1977 COM O “iNDICE” DE 2008}

\begin{tabular}{|c|c|}
\hline $\begin{array}{l}\text { Poesia de António Maria Lisboa } \\
\text { Organização: Mário Cesariny } \\
\text { (Assírio Alvim, 1977, } 409 \text { páginas) }\end{array}$ & $\begin{array}{c}\text { Poesia António Maria Lisboa } \\
\text { Organização: Mário Cesariny } \\
\text { (Assírio Alvim, 2008, } 238 \text { páginas) }\end{array}$ \\
\hline $\begin{array}{l}\text { Nota prévia assinada por Mário Cesariny } \\
\text { (p. 07-15) }\end{array}$ & $\begin{array}{l}\text { Apresentação datada de } 1958 \text { e dado } \\
\text { biográfico assinados por Mário Cesariny } \\
\text { (p. 07-09) }\end{array}$ \\
\hline $\begin{array}{l}\text { Plano } \\
\text { (situado no começo do volume p. 17-19) }\end{array}$ & $\begin{array}{l}\text { Índice } \\
\text { (situado no final do volume p. 236-238) }\end{array}$ \\
\hline I A poesia feita por todos & I. A afixação proibida; \\
\hline Livro I & II. Erro próprio; \\
\hline $\begin{array}{l}\text { Mistérios Medos e Mais Coisas (com } \\
\text { Henrique Risques Pereira) } \\
\text { Poemas Colectivos (com Carlos Eurico }\end{array}$ & $\begin{array}{l}\text { III. Aviso a tempo por causa do } \\
\text { tempo; }\end{array}$ \\
\hline $\begin{array}{l}\text { da Costa, Henrique Risques Pereira, } \\
\text { Pedro Oom, Mário Cesariny e Fernando }\end{array}$ & IV. Ossóptico e outros poemas; \\
\hline Alves dos Santos) & V. Isso ontem único; \\
\hline $\begin{array}{l}\text { Livro II } \\
\text { Máquina de Guerra }\end{array}$ & $\begin{array}{l}\text { VI. Exercício sobre o sono e a vigília } \\
\text { de Alfred Jarry; }\end{array}$ \\
\hline $\begin{array}{l}\text { Livro III } \\
\text { Erro próprio }\end{array}$ & O senhor cágado e o menino; \\
\hline $\begin{array}{l}\text { O Cadáver-Esquisito à Mesa Pé-de-Galo } \\
\text { (com Mário de Sá-Carneiro, Alexandre } \\
\text { O’Neill, Mário Cesariny e Pedro Oom) }\end{array}$ & $\begin{array}{l}\text { VIII. Carta aberta ao Snr. Dr. Adolfo } \\
\text { Casais Monteiro; }\end{array}$ \\
\hline $\begin{array}{l}\text { Livro IV Carta aberta ao Snr. Dr. Adolfo } \\
\text { Casais Monteiro Aviso a tempo por } \\
\text { causa do tempo } \\
\text { Livro V Introdução ao estudo sistemático } \\
\text { de “Malaquias ou a história de um }\end{array}$ & $\begin{array}{l}\text { IX. Introdução ao estudo sistemático } \\
\text { de "Malaquias ou a história de um } \\
\text { homem barbaramente agredido", de } \\
\text { Manuel de Lima ou melhor: } \\
\text { introdução à acção sistemática atentro } \\
\text { do princípio de Malaquias; }\end{array}$ \\
\hline $\begin{array}{l}\text { homem barbaramente agredido", de } \\
\text { Manuel de Lima, ou melhor: introdução }\end{array}$ & X. Cartas; \\
\hline
\end{tabular}




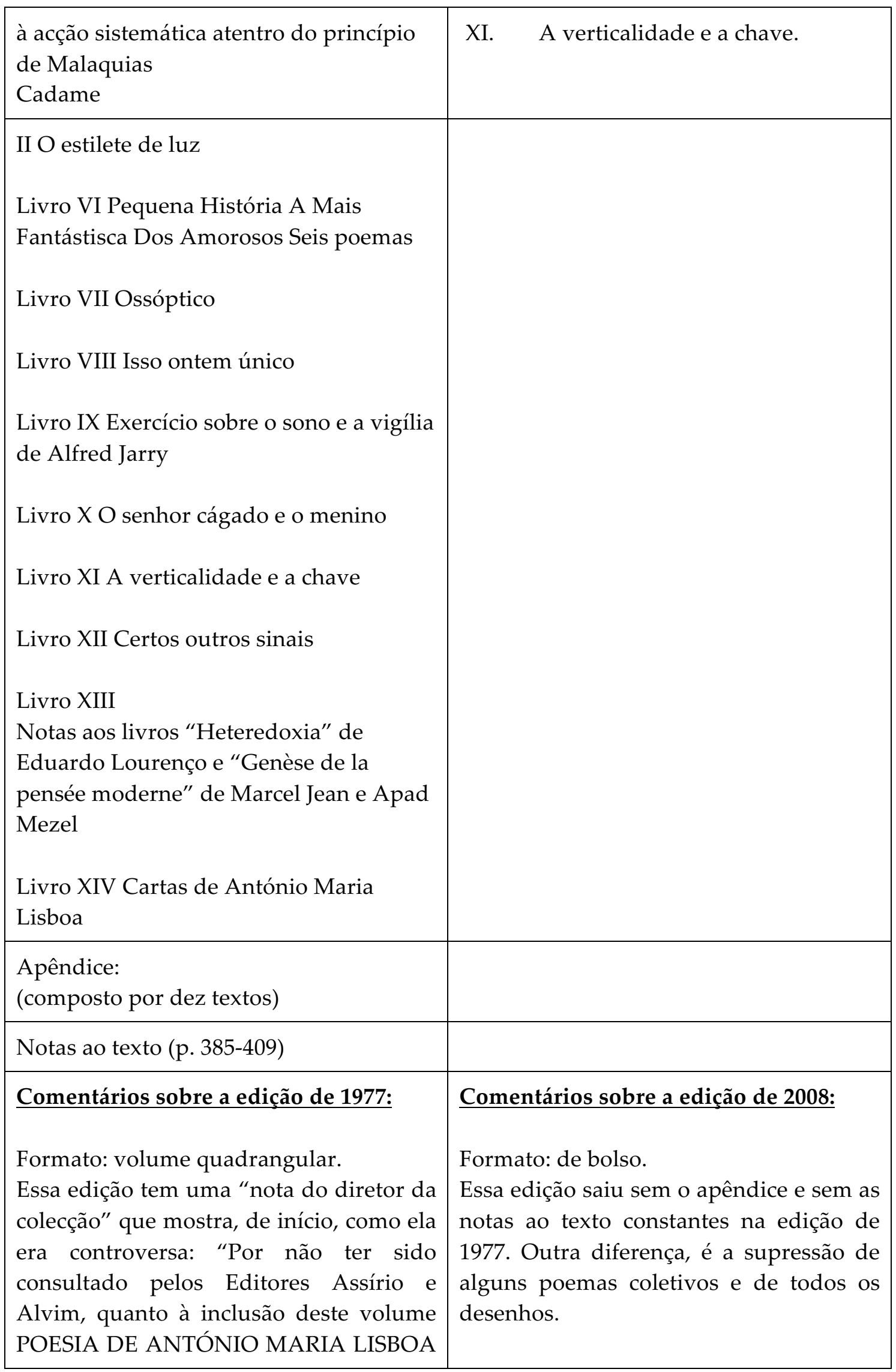


na colecção DOCUMENTA POÉTICA (que tem sido por mim dirigida encomendando as Obras aos seus Autores e com eles discutindo livremente quanto a matérias e critérios) declino qualquer responsabilidade sobre o seu conteúdo que aliás até hoje, 20 de Outubro de 1977, me não foi dado a conhecer, nem pelos Editores, nem pelo Autor da Obra. E.M. de Melo e Castro" (p. 6). E, logo na sequência, uma "nota do editor": "O editor não subscreve parte das afirmações e acusações produzidas neste volume pelo responsável da edição, Mário Cesariny de Vasconcelos"' (p. 6).

Recebido em 19 de junho de 2020

Aprovado em 05 de setembro de 2020

Licença: (c) (i) (\$)

Danilo Rodrigues Bueno

Doutor e Mestre em Letras pelo Programa de Literatura Portuguesa da Universidade de São Paulo, Brasil. Graduado em Direito pela Faculdade de Direito de São Bernardo do Campo, São Paulo, Brasil.

Contato: buenodanilo@hotmail.com

(D): https://orcid.org/0000-0000-0000-0000 